\title{
DIGITALIZATION FOR INCREASED ACCESS TO HEALTHCARE SERVICES: CASE OF LATVIA
}

\section{VLADIMIR MENSHIKOV}

Dr.sc., Professor,

Daugavpils University, Latvia

vladimirs.mensikovs@du.Iv

\section{IRENA KOKINA}

Dr.sc., Professor,

Daugavpils University, Latvia

irena.kokina@du.Iv

\author{
VERA KOMAROVA \\ Dr.oec, \\ Daugavpils University, Latvia \\ veraboronenko@inbox.Iv
}

OLGA VOLKOVA

PhD student,

Daugavpils University, Latvia

olga.volkova@du.Iv

\begin{abstract}
The aim of the present study is to consider a range of problems that are to be solved during the implementation of the projects aimed at increasing the access to healthcare and based on the achievements of the new technological order on the example of Latvia, primarily the e-health project. Since January1, 2018, the use of the e-health system in Latvia is mandatory, but so far only the "Digital Prescription (e-prescription)" project has been functioning at full capacity. The experience with the introduction and the use of digital medicine in Latvia indicates a large range of problems faced by state institutions and local self-government institutions, medical establishments, medical personnel and patients. A systematic vision of the problems of implementing digital medicine requires a necessity, at least, of taking into account and solving seven relatively independent tasks: technical and technological, economic, legal, organizational, managerial, social, psychological, and cultural ones. In terms of systemic vision, the assessment of these aspects of the e-health programme implementation is presented by means of an extensive use of data retrieved from international organizations, Latvian state statistics, scientific research studies, including the ones carried out by the authors. The main conclusion of the study is the need for the theory and the practice of the increasing access to healthcare based on digital medicine, taking into account a more complete variety of factors that stimulate and constrain this process, and involving specialists from the sphere of social sciences. The importance of the problem has significantly increased amid COVID-19 crisis. So far, there are no relevant statistics on the availability of medical services during the pandemic, but individual assessments and recommendations of specialists indicate the need for a speedy and coordinated global promotion of e-health. The example of Latvia demonstrates that there are significant barriers to e-health. An accelerated decision process regarding the given issue is not always related to the economic resources of the country. Our studies show the importance of solving institutional problems, ensuring the better mainstreaming of psychological, socio-cultural and social factors. In our opinion, the upcoming project by the Latvian researchers "Latvia. Human Development Report" should be devoted to the most topical issue of e-health. While working on this project, it would be crucial to use the experience of specialists from other countries where similar studies have been conducted (Georgia, Ukraine, Poland, etc.) and experience of international cooperation in the framework of other social projects has already been accumulated.
\end{abstract}

\section{KEYWORDS: DIGITAL MEDICINE, HEALTHCARE ACCESSIBILITY, E-HEALTH, BLOCKCHAIN, DIGITAL DEVELOPMENT.}

For citation: Menshikov, V., Kokina, I., Komarova, V., \& Volkova, O. (2020). Digitalization for Increased Access to Healthcare Services: Case of Latvia. Globalization and Business, 10. 25-34.https://doi.org/10.35945/gb.2020.10.002

The covid-19 pandemic once again has demonstrated the fact that, regardless of the political rhetoric of some leaders of world powers, the residents of all the continents are increasingly exposed to the same threats to their health and quality of life. In the article "Digitalization for increased access security to healthcare services in Latvia" we have already explored the barriers and limitations that significantly affect the implementation and use of digital medicine, making it difficult for the residents of Latvia and other countries to access timely and high-quality medical services, which is also a significant aspect of national security and sustainable economic development (Menshikov \& Volkova, 2019). The epidemic crisis clearly shows the role of cooperation between all countries and nations in solving the emerging medical problems, as well as new opportunities for solving them through the more widespread and effective 
use of the achievements of the new technological structure artificial intelligence, blockchain technology, smart machines and other innovations, that are significantly influencing the health sector.

Whereas communities were previously coming together because of the geographical position, today cooperation is based on common interests, and the newest technologies. At the new historical stage, in the age of informatization and computerization, it is appropriate to consider social relations from a new perspective and in a new context.

The influence of Information Communication Technologies (ICT) on access to healthcare is also being actively studied. The experts believe that the introduction of the e-health system should help to overcome the numerous economic, geographical and social barriers that impede access to healthcare, as well as to compensate for the shortage of medical personnel (OECD, 2010), (Deloitte Centre of Health Solutions, 2015). The influence of ICT on accessibility, namely on the universal access of the population to health care services, is being discussed in numerous global studies (AlShorbaji, 2013), (Roth, et al., 2015), (WHO, 2016), (NovilloOrtiz, etal., 2018). In particular, Al-Shorbaji (2013), analysing the issues related to the role of ICT play in the increasing of access to healthcare, focuses primarily on the role of the information literacy of medical workers: the use of innovative approaches and eLearning in support of health education and education of health work force has been established as a major area of interest for both WHO and its member states within the e-Health domain; the Health Academy eLearning modules and the collaboration with member states and technical departments have taken a new turn through the current effort to conduct systematic reviews of the evidence for elearning. Of course, in reality, there are much more problems related to the introduction of ICT (e-health systems and other achievements of digital medicine), and these problems are not related only to information literacy.

Without doubt, the access to healthcare is also determined by the economic impact of the e-health system. First of all, this is the impact on public health expenditure. In an aging society, we spend on healthcare more than ever. Since 1970, the life expectancy of a child born in OECD countries has increased by 10.7 years. On average, we now live more than ten years longer than almost fifty years ago (even longer in the EU - for 15years). At the same time, the average health expenditure almost doubled from $4.5 \%$ of GDP in 1970 to 8.9 in 2015 (Arak \& Wójcik, 2016-2017). As soon as the introduction of the e-health requires huge public investments, there is a necessity to provide evidence of obvious benefits to patients, healthcare providers and the public at large (OECD, 2010).

As a rule, the emphasis is on the technical feasibility and successful implementation of the system, while the economic approach is of secondary importance. However, as WHO experts note, it is economy and value to society that ultimately determine whether the system will survive. Health organizations, public or private, must predict a positive return on investment (financial or others) in order to receive continued financial, institutional and political support for their efforts. Nevertheless, although health organizations can (and in many cases do) improve care and meet unmet public healthcare needs ("social justification") by means of introducing ICT, it is usually difficult for these organizations to demonstrate economic benefits ("Economic justification"), including the data on whether their own financial performance is improving (OECD, 2010).

To date, the project for the establishment of a global telecommunications network in medicine, funded by the World Health Organization (WHO) is at the final stage of its implementation. The project includes electronic exchange of scientific documents and information, accelerated search with access via telecommunication networks, conducting electronic voting of experts, video conferences, and possibility to conduct electronic voting and arrange meetings (WHO 2016).

The apparent advantages of the e-health system include the possibility of "erasing" the space-time boundaries in the field of healthcare and the increase in the speed of processing information with the help of modern technologies: "the sooner the treatment is started, the greater the chances of full recovery are". According to our assessment, digital medicine has a positive effect on all four mutually intersecting parameters of accessibility defined by WHO: information accessibility, physical accessibility, economic accessibility, non-discrimination. Unfortunately, the project managers who work in this area not always focus on all these e-healthcare benefits.

Experts state that digital medicine rests on three pillars: electronic flow of documentation, telemedicine (technologies for remote consultation with a doctor, exchange of information between medical organizations) and the use of mathematical data processing methods. It is the third component of digital medicine (a huge leeway for the application of artificial intelligence methods) that actually gives medicine a new quality. Our traditional medical records contain a huge amount of information. But, from a global point of view, all this wealth, figuratively speaking, is going to waste. However, if medical records are digitised into an electronic form, then mathematical algorithms can analyse all these data and find patterns in them that are imperceptible to the human eye. Besides, this will make it possible not only to make the most accurate diagnosis, but also to predict the risk of developing a particular disease long before the onset of its clinical symptoms.

The Ministry of Health of the Republic of Latvia started to think about the e-health project as early as 2003, the working group appeared in 2005, but a specific plan was written only in 2006. A year later, its implementation was initiated.

It was assumed that, as a result of the project, the efficiency of the work of medical personnel would increase by $22 \%$, the outpatient waiting time would be reduced by $16 \%$, and the contact time between the healthcare provider and the patient - by $5 \%$. However, doctors themselves should see a greater impact- according to projections, the minutes that are now spent on studying the patient's medical history will be almost a third less.

The e-health programme, i.e. a state long-term priority 
Figure 1: E-health programme in Latvia-stages of development

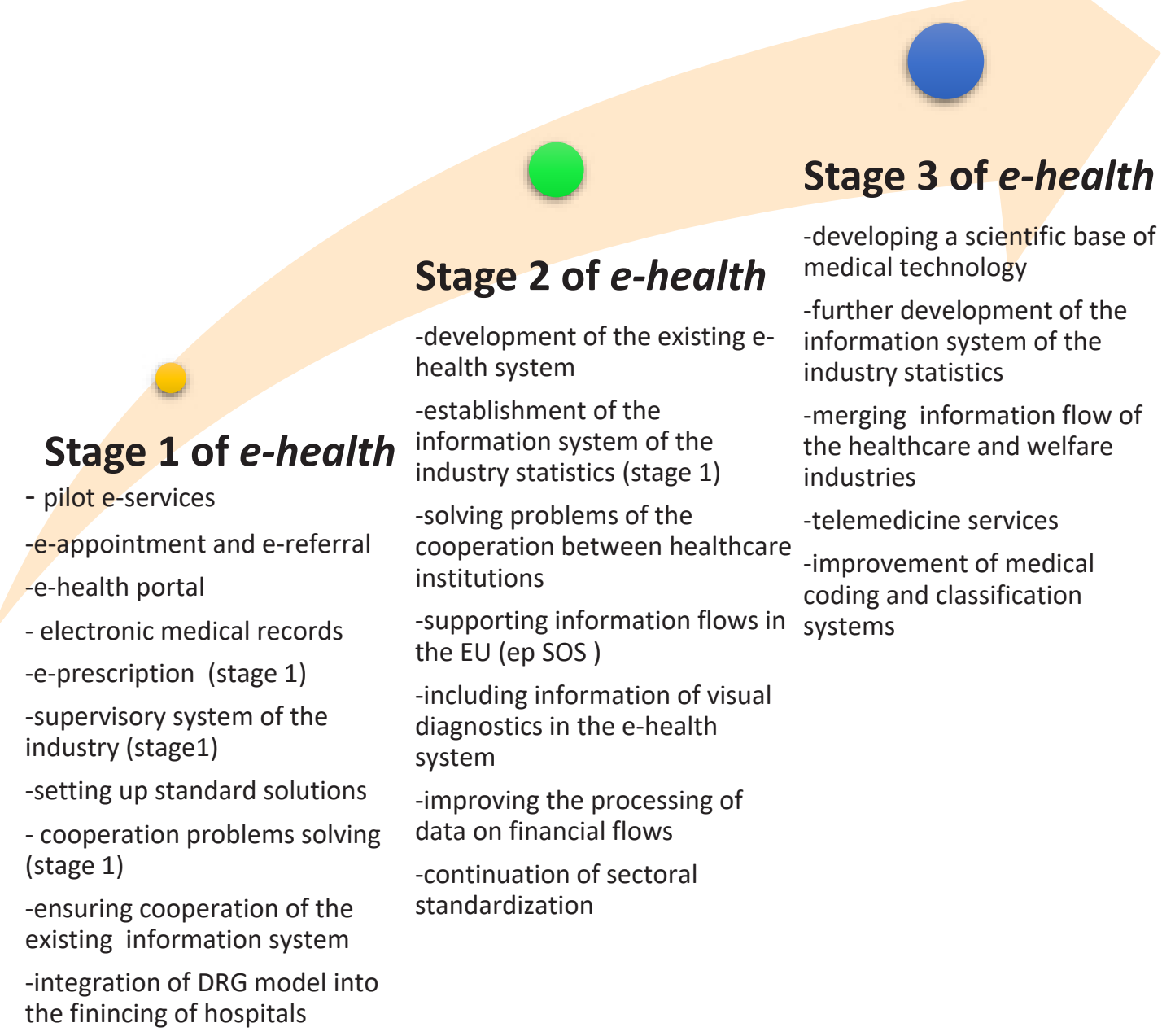

Source: The Ministry of Health of the Republic of Latvia, (Gabalina 2012)

programme to improve the healthcare system in Latvia, envisaged three stages of its implementation (see Figure 1).

However, only from January 1, 2018, the use of the e-health system in Latvia is mandatory. For the time being, only the "Digital Prescription (e-prescription)" project has been functioning at full capacity. Every year, up to 15 million of prescriptions are written out. The new system has allowed to automate the process, to track the entire life cycle of a prescription from the moment it is written out until the dispensing of the medicine. It has reduced the time used for filling in documentation, the risk of errors due to the notorious "doctor's handwriting", etc. The system is integrated with a register of medicines and a list of compensated medicines.

The experience in introducing and using digital medicine in Latvia indicates a large range of problems faced by state and local self-government institutions, medical establishments, medical personnel and patients, which significantly impede the expansion of the access to healthcare. The most significant of them can be considered in the complex, which includes barriers and restrictions that are significantly different in their characteristics. In this aspect of our research analysis, we propose to consider the following 7 groups of such characteristics.

\section{Technical and technological problems}

The healthcare industry has long been in need of change, and today there are many opportunities for blockchain technology to lead the transformation. But the technology has already been in existence for more than 10 years; and we will be right claiming that it has made little changes so far. Except, perhaps, the financial sector that has experienced its impact.

Interest in blockchain technology has become more noticeable in the last 3-4 years, including the interest shown to it in the sector of healthcare. The increased demand for blockchain technology can be proved by the results of a study carried out in October 2017 by a team "BlackBook" (Black Book Research 2017). It surveyed 88 healthcare consumers (among them were representatives of insurance companies, consumers of medical services) and 276 healthcare providers (specialists responsible for technology process, managers and IT specialists).

"BlackBook" revealed that $19 \%$ of managers in medical organizations and $76 \%$ of representatives paying for medical services were considering the possibility of using blockchainbased technologies or had already been using them. $70 \%$ of 
various organizations that pay for medical services expected blockchain integration into existing systems, and $9 \%$ of healthcare providers were planning to start using the new technology as early as 2018. Accordingly, the increased attention to distributed ledger technology had led to an understanding of the potential application of technology in the healthcare system. These conditions had provided fertile ground for teams and organizations wishing to integrate blockchain technology into existing projects or develop new ones that would meet the requirements of high standards.

In 2013, the European Commission conducted a largescale survey on the deployment of e-health among general practitioners. Denmark achieved the highest score (2.49 out of a possible 4); it was followed by Spain (2.17), Norway (2.16) and Estonia (2.13). Latvia and Lithuania had the lowest scores -1.50 and 1.35, respectively (Codagnone 2013).

A study on the deployment of e-health in European hospitals was also conducted in 2013 (in 2010, a similar survey was conducted, but with a smaller sample). 2 indicators were evaluated:

1) distribution in relation to four "core" dimensions of e-health: digital infrastructure; application and integration; information flows and health information exchange; security and privacy.

2) availability and use concerning digital applications and functionalities: electronic health record; clinical decision support tools; TeleHealth (remote medical consultation) (European Commission 2014).

Hospitals in the Nordic countries achieved higher scores on both indicators. Hospitals in Eastern and Southern Europe had lower scores. Larger hospitals and public hospitals recorded higher scores on both indicators. Latvia had relatively low scores and was ranked 25th out of 30 countries on both indicators. Overall, these results show gaps in governance with regard to data security, privacy and interoperability. Only $57 \%$ of hospitals reported having a strategic plan for e-health.

Experts of the European Commission point out that proceeding from the results obtained, it is necessary to improve the adoption of digital technologies in both primary healthcare and hospitals across Europe in order to fulfil the vision outlined in the European Commission e-Health Strategy (OECD/EU 2016).

As Digital Economy and Society Index (DESI) published by the European Commission shows Latvia ranks 18th in the EU in terms of the development of digital economy and society (European Commission, 2019). Finland ranks 1st; Sweden, the Netherlands, and Denmark are the leaders as well. The DESI is a composite index that summarises relevant indicators on Europe's digital performance and tracks the progress made by EU member states in digital competitiveness taking into account five key components: availability of high-speed Internet, digital skills of the population, level of the use of Internet, integration of digital technologies into business and digital public services (such as e-government and e-health). Among the DESI sub-indices there are some indicators that are directly related to the use of ICT in the healthcare system. The e-health indicator is a percentage of state residents who use e-health services. By this indicator, Latvia is in 18thplace (14\%). Estonia and Finland are the leaders in the ranking - in 2017, 49\% of the population of these countries used e-health services (Figure 2). The EU average is $18 \%$ (European Commission, 2019).

The frequency of the use of electronic resources in the search for medical information serves as an indicator for the evaluation of the health information infrastructure, including the digital literacy of the population that is extremely important at present as it represents a set of skills and competencies for secure and efficient use of digital technologies and Internet resources (Menshikov \& Volkova, 2019).

"Medical Data Exchange" is another DESI sub-index that reflects the development of the e-health system. It shows a number of general practitioners that use electronic networks sharing medical data with other healthcare providers and specialists. According to this index, Latvia is in 21stplace with an indicator of $21 \%$. This is a relatively low figure with the EU average of $43 \%$ (European Commission, 2020).

Figure 2. The Proportion of the EU residents that use e-health services (\%)

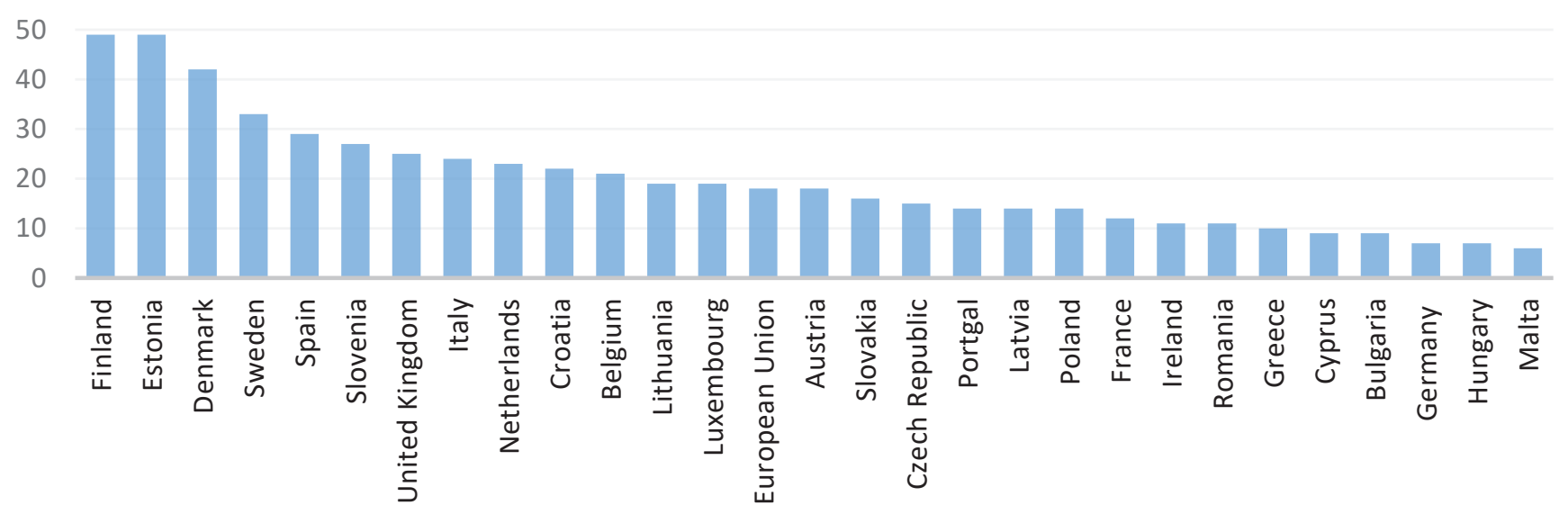

Source: (European Commission, 2019), (Eurobarometer, 2017) 
With regard to the DESI sub-index "e-Prescription", Latvia has a relatively high score for this indicator and is in 7 thplace in the ranking of the EU countries with an indicator of $91 \%$. The EU average is $50 \%$. European Commission experts note that there is a large gap between the countries that showed results above the EU average and the countries that showed results below the average (European Commission, 2019).

2. Economic problems that indicate rather large financial expenses for the promotion of digital medicine. Thus, according to the information provided by the company StartUpHealth, in 2017, investment in digital medicine was $\$ 11.5$ billion, which is $\$ 3.5$ billion more than in 2016 (StartUpHealthInsights 2018).

At the same time, the fourth quarter of 2017 was a record for all the years: in this period, 227 investment transactions with a total amount of $\$ 2.3$ billion were concluded. In addition, the company noted that the year ended was a record in the number of transactions: 794 contracts that exceeded \$1 million. As before, most of these transactions $(65 \%)$ are related to projects that are at an early stage of their implementation. Though, the number and volume of investments in the companies that are at the later stages is increasing.

The top 5 deals of 2017 (excluding OutcomeHealth contract in the amount of $\$ 800$ million) are Grail (\$914 million), GuardantHealth (\$360 million), Peloton (\$325 million), Auris (\$280 million), 23andMe (\$250 million).

The top 5 sectors of the industry that were invested most were systems aimed at the improvement of patient experience (Patient/Consumer Experience) - \$1.64 billion, personalized medicine $-\$ 1.59$ billion, big data and analytics - \$1.39 billion, medical devices - \$1.37 billion, and systems for a healthy lifestyle (wellness) - $\$ 1.12$ billion.

The most active geographic areas where investments were made in this field were San Francisco and New York (USA), London (UK), Tel Aviv (Israel), Bangalore (India), Stockholm (Sweden), Toronto (Canada), Beijing (China), Boston (USA) and Paris (France).

In 2018, the United States still was the most active region in terms of investment, as such transactions were most often recorded in San Francisco, New York, Boston and Los Angeles. As for the rest of the world, the UK, China, Sweden, India, Singapore, Canada and Israel were the most active ones.

In 2018, the major investments were made in the following sectors of the industry:

- patient empowerment (\$2.1 billion in 149 transactions);

- wellness (\$1.6 billion - 64 transactions);

- biometric data acquisition

(\$1.5 billion - 50 transactions);

- clinical workflow (\$1.1 billion - 98 transactions);

- admin workflow (\$1.0 billion - 85 transactions);

- research (\$964 million - 37 transactions);

- personalized health (\$857 million - 54 transactions);

- medical insurance (\$854 million - 12 transactions);

- population health (\$701 million - 27 transactions);
- education (\$280 million - 11 transactions) (StartUpHealthInsights 2018).

In Latvia, against the backdrop of an impressive amount of investment in digital medicine in the leading countries, expenditure on this sector does not seem very large.

Thus, the total amount allocated for the projects to implement the e-health system in Latvia, co-funded from the European Regional Development Fund, was initially EUR 10.2 million. This financing was distributed among eight developers: LattelecomTechnology -EUR 2.9 million; Datorzinībucentrs and ABC Software -EUR 3.5 million; Involv, TietoLatvia and ABC Software -EUR 576 000; Lattelecom and Exigenservices Latvia -EUR 3.2 million.

However, from the very beginning there was a problem of the effective use of this financing. The state controllers of the State Audit Office of the Republic of Latvia claimed that the loss of revenue for the state due to the inactive e-health project in 2013-2015 was EUR 3 million. This is exactly this amount of money that could be saved if only at least a part of the services had worked. The total amount of EUR 760,000 was spent unproductively or uneconomically, and EUR 483,000 was spent for inappropriate purposes.

In this context, a comment made by one of the users of the portal Delfi.lv, who familiarized themselves with the evaluations given by the controllers, deserves attention: "As an independent developer, I estimate the implementation of the part that is visible to individuals as a work done for 120 hours. This includes an optimally configured database, design, forms, etc. Everything, entirely. Suppose that the part for doctors is more difficult, it will take 200 hours. Let's throw another 50 hours for related work. Total 370 hours. My rate is 45 euros per hour. Total 16650 euros for the entire system, which will not be slow, will look normal and will operate normally. OK, let's increase it up to 50,000. Anyway, it's a lot less than millions. Where have all these millions gone? Why was it necessary to attract so many companies? The answer, apparently, is simple: corruption and feeding. This is what KNAB should do! but they won't, of course". Of course, of course, nothing is ever that simple, but the quality of the system and the cost of its implementation in Latvia are certainly far from optimal values.

\section{Legal aspects, security issues}

It is necessary to pay attention to the fact that, despite the obvious success, the development of digital healthcare still has certain limitations in the practical aspect; this situation is due to the existing ethical and legal risks of using electronic technologies in medicine. First of all, it is about respect for confidentiality of patients' data, respectively, medical confidentiality, which is one of the basic rules in deontology. In the legal aspect, the risks of the development of digital medicine are caused by the inconsistency of international legal norms regulating the activities of treatment-andprophylactic institutions and their personnel with the current national legislation in the field of healthcare.

The question arises: would it be possible for evildoers 
to take advantage of this personal information? Hackers will give a lot to get the medical file of a major politician or a businessman. To prevent this from happening, a multi-level system of personal data protection is to be produced.

That is why, in March 2020, Europe's largest mobile operators, Deutsche Telekom, Orange, Telefonica, Telecom Italia, Telenor, Telia, A1 Telekom Austria and Vodafone began negotiations with the European Commissioner for Internal Market and Services on the provision of their customers' geolocation data to track the distribution of COVID-19 (Galitskih, 2020).

The European Commission expects that such a database can be very useful for tracking the contacts of people with COVID-19. It is also needed to monitor compliance with quarantine requirements. But since geolocation data are personal data, there is a reasonable doubt: is it legal to collect such data in the European Union and will it lead to total surveillance by the states of their citizens?

There are doubts in absolute security in respect to the Zoom application, which has become especially popular during the coronavirus pandemic. The demand for a video conferencing application has skyrocketed because it promised everything you needed to work remotely: simple management and stable communication for video conferencing with a large number of participants. However, apparently, the enthusiasm was premature.

Because of the coronavirus pandemic, videoconferencing has become common for politicians, as criticism due to non-compliance with the principles of security and data protection is growing considerably. There is a tendency in growth of number of cases when unregistered participants intruded into Zoom video conferences. In this regard, the FBI has officially announced the threat of espionage in relation to the use of this application. Earlier it became known that Zoom encryption codes passed through a server in China (Nering, K., Gunkels 2020).

In addition, one cannot exclude technological risks due to the complexity of the equipment used. Y. N. Harari's report at the Davos forum (January, 2018) contained shocking warnings about "digital dictatorship" which may arise as a result of the concentration of information in integrated centres. Especially information on health. "When computers start tracking not only our emails, messages and money, but also our bodies, the vulnerability of each individual will increase ... When you combine the information technology revolution with the biotechnology revolution, you get an opportunity to hack people" (Harari 2018).

In the world, the scale of computer crimes has become avalanche-like. They shake the largest banks, corporations and even military departments, secret services and governments of many countries. This indicates a sharply increasing danger of using computerized data storage and processing systems, especially for ordinary people who trust their personal data to these systems. Stricter, more precise legislation is needed to protect us from outside interference in medical information. To avoid this, it is necessary to create and improve a multi-level system for the protection of each patient's personal data.

\section{Organizational and managerial problems}

The transition to digital medicine is a complex management task requiring a well-thought-out and well-considered strategy. This is expressed in the choice of the level of cooperation, coordination of actions, "networkization" and integration. The elaboration of a quality strategy depends on the organizational and managerial experience of managers, who are able to offer and implement optimal under specific conditions solutions to the many complex problems of digital medicine. Of course, personal and professional competencies of a manager, who makes decisions, largely determine the success or failure in the deployment of the entire set of elements of the most complex system of a new technological order.

In our assessment, these were not financial, but organizational problems that were primarily hampering and holding back the deployment of digital medicine in Latvia. For more than 10 years, the e-health project had been being implemented according to the old plans drawn up in 2006-2007, when many more significant technological innovations used in digital medicine even did not exist. The terms of the project's implementation were constantly postponed (in general, initially the project was supposed to be completed in 2010). Because of the economic crisis, the "contracting authority" responsible for the project was being changed several times. Thus, in 2009, the functions of deploying the e-health system were given to the Centre for of Health Economics, and, from the end of 2011, the project was transferred to the National Health Service which is implementing it now.

Having started the work, the current Minister for Health in Latvia, I. Vinkele, decided to even suspend the 3rd stage of the elaboration of the e-health system, for which it was planned to spend EUR 5 million. According to I. Vinkele, e-health is a failed system, a sick from birth and incorrectly attended at delivery child. She personally would completely curtail the current e-health project. But, to her regret, the fact is that there are certain commitments to funding from the EU funds, which the Latvian organizers of healthcare assumed by implementing e-health.

According to Edgars Labsvīrs, the director at National Health Service, over the next three years10 million euros should be invested in the completion of the e-health system to make it function effectively. It is planned to introduce the functions of medical registration to doctors and issuance of electronic referrals. In addition, National Health Service has already begun its work on systematizing the databases and improving the exchange system (Baltniews, 2020).

The decisions made by politicians and ministerial officials during the emergency caused by the coronavirus outbreak are far from being optimal and managerial. Pēteris Apinis, a well-known physician and the President of Latvian Medical Association, believes that the decisions made by the Latvian government to prevent the spread of coronavirus are reckless. Apinis writes:

"At present the senseless activities of the Latvian politicians are being most clearly demonstrated by two strategies. 
1) To force all the residents to stay at home, watching the outer life from behind their curtains, and only in exceptional cases they can go to a store to buy bread and milk. No sports and walks, to close gyms and swimming pools.

The wackiest politicians with a "background of a cop" require prohibitions on movement, when only the military and the police forces will be allowed to appear in the streets, and the sick will be marked with a special sign (in ancient times, in Riga, lepers were using bells to inform about their coming).

2) To prohibit outpatient treatment and day hospitals for any chronic diseases, with the exception of infections caused by SARS-2."

According to the doctor, both of these proposals are absurd and directed against public health, they can only achieve the worst results of the COVID-19 pandemic in Latvia. To close outpatient care is a very cruel experiment. Apinis noted that such actions are directed against human health, against resistance to the disease (Apinis, 2020).

Indeed, at present, remote medicine at best is undergoing a period of formation and remote treatment of chronic diseases on a large scale is hardly possible during pandemic.

\section{Social problems}

It is known that the problem of unequal access to medical services, despite the efforts made by the world community, is due to the social determinism of human health in modern society (Menshikov, Volkova et al. 2017). Therefore, the overcoming of this problem entails certain socio-economic risks and determines a necessity to search for new approaches for solving it. In the conditions of the modern development of the global community, the deployment of information and communication technologies (ICT) into medical practice and system organization of health services, and the creation of a digital health system seem to be one of the possible approaches. The use of digital technologies in medicine has allowed to produce completely new forms of interaction between medical service providers and their consumers.

In the latest scientific literature, the issue related to the impact of e-health on social inequality of society is topical (Latulippe, Hamel, Giroux 2017). The authors of numerous studies have identified a number of socio-demographic characteristics that determine a part of population that is at risk of social inequality and limited in the possibilities of using e-health tools.

Universal health coverage means that all people, wherever they are, have access to health services without the risk of financial deprivation caused by the health services received. There is a growing recognition on the part of WHO that e-health plays a unique and decisive role in achieving universal health coverage; it expands the range of health services, increases the transparency and accessibility of prevention care and medical information, expands the population base for using the offered health services and stimulates innovations and efficiency gains (WHO 2016, a) (WHO 2016, b). However, according to the latest statistics gained from Eurostat and other European research centres, electronic medicine has not had a significant influence on the availability of medical services. As our correlation analysis has demonstrated, there are no statistically significant relationships between the indicators of the access to healthcare and the indicators of IT development in the field of medicine in the EU countries.

The concept of universal health coverage also takes into account that healthcare does not function separately from other social factors and that many of the factors that are not related to public health at first glance often have a direct impact on it. Under this concept, all sectors of society have obligation that they must fulfil their interrelated roles in ensuring health, going beyond traditional approaches to healthcare and social support and fostering intersectoral collaboration and action to achieve positive changes in population health indicators (WHO 2016, a).

It should be noted that, due to socio-economic differentiation of developed and developing countries, the ways of the use of digital technologies in healthcare of these states have certain differences. For example, in Europe and America, they are widely used for diagnosis and clinical treatment, while in regions with low per capita income, their deployment is limited and, so far, is used to collect data, to disseminate information and to set up communication between healthcare providers and their consumers. This situation gives some researchers a reason to consider the limited use of digital technologies in solving the problem of social inequality in health (Lyadova 2018).

The first "non-economic" problem the residents tell about during sociological surveys is the poor quality of healthcare and the inaccessibility of medicine. At the same time, trust to doctors is reducing, and the existing system for assessing the quality of medicine raises many questions. Public dissatisfaction with healthcare is quite predictable, since the state is chronically underfunding this area.

Of course, digital medicine has a significantly different influence on the social stratification of society, on social classes and strata, population of different regions, age and other groups with demographic specificity. The ubiquity of information and communication technologies is changing everything, including the concept of social norms, factors and criteria of social stratification. It is high time to introduce into scientific use such a factor of social stratification as online or offline, as well as the concept of "digital deprivation" or "digital literacy". Researchers understand digital deprivation as a situation when a way of life, that is customary for most people, turns out to be impossible because of the lack of ICT skills or a desire and an ability to acquire them. Although today the non-use of a wide spectrum of electronic services is not perceived yet in our society as deprivation, the narrowing of opportunities and the disadvantaged offline individuals are becoming more noticeable. Anyone, who does not live online today, lives in a world of increasing deprivation. There is a need to apply a deprivation approach to poverty introduced by the British specialist P. Townsend (Townsend 2010) in the consideration of digital deprivation.

This will help to overcome the technocratic approach to 
the study and use of ICT. In world science and practice, such an approach has long been complemented by a humanitarian one, in which the main focus is not on the technical side of things, but on a person, who is using information and communication technologies and services, and on the studies of their use.

\section{Psychological problems}

In our opinion, one of the most significant factors that is holding back the growth of digital medicine in Latvia is not the absence of ideas, but the existence of high psychological barriers and a problem of audience trust, which makes the cost of the paying user deadly high. No less significant is the fact that a part of medical personnel is wary and restrained towards digital medicine.

At the same time, the situation with the coronavirus pandemic has clearly and significantly demonstrated the role of the latest technologies in ensuring the safety of society as a whole, its psychological state, etc. Isolation, risk of serious illness, job loss, change of habits, uncertainty in the future are stresses. Therefore, in such periods, the demand for professional psychological and psychiatric help is growing. The latest technology allows one not to wait until the end of the quarantine and register for an online consultation.

Psychological online consultations with experienced professionals have been happening for quite some time. As to doctors - psychiatrists and psychotherapists - there are difficulties: to make a diagnosis and prescribe medications remotely. It is difficult, at least because of laws and bureaucracy. At present, coronavirus patients at home care are consulted remotely. It is good, when along with this, the legislation on telemedicine is rapidly changing.

When the pandemic is over, it makes sense to wait for the growth of telemedicine platforms, diagnostic algorithms, and along with them - for the growth of services for selection of psychologists and psychotherapists. Messengers and video communications, of course, should help to overcome separation from the loved ones, especially for the elderly people. Loneliness and narrowed social circles are the main stress factors during quarantine.

Though it should be stated that psychological factors, when introducing and using digital medicine, are felt not only in emergency situations.

The former Minister for Health, now a Member of the Saeima, Anda Čakša, agrees with the words of the new head of the Ministry of Health, Ilze Vinkele, that the healthcare system in Latvia is "not oriented to a human, as it is selforiented".A. Čakša believes that the entire process that has been going on for 28 years was carried out according to this scheme: "I often had to say to the National Health Service there is a feeling that you yourself cannot understand what a mess you have made". According to her, sometimes it seemed that in Latvian medicine even the doctors themselves did not understand the essence of the process and did some things in a certain way just because someone had come up with these suggestions.

Only a year after the launch of the e-health system, the organizers of our healthcare finally decided to involve doctors and other medical workers into it to increase its efficiency. Recently, the new head of the Ministry of Health of the Republic of Latvia, I. Vinkele, told about the current process of the further implementation of the e-health system: "We are also creating a council of users who will have to work with this miracle every day (LatvijasRadio 4, 2019). One of the big mistakes of the previous stage - doctors were not asked what they needed from this system, how functional it was. In order not to repeat these mistakes, the elaboration of the third stage is happening with the direct participation of the people, who will use e-health"-it is about time.

\section{Sociocultural problems}

New phenomena of the technocratic world, its volatility, fluidity, multi-platform and multi-channel nature make the contemporaries live in conditions of media redundancy and form a certain set of skills, called "digital literacy". N.D. Berman gives the following definition of this concept: "Digital literacy is defined by a set of knowledge and skills that are necessary for the safe and effective use of digital technologies and Internet resources ... this is a person's ability to use digital tools (in the broadest sense) with benefit for himself. The concept of "digital literacy" includes three components: digital competence, digital consumption and digital security". Digital literacy encompasses a number of technical, personal and intellectual skills such as: a skill to quickly search, to analyse and to evaluate information, to navigate in media streams; skills of lifelong learning, dialogue with the mass media, recognition of various manipulations from the media, as well as from individual users and user groups, etc. (Shamshurin 2018).

A large-scale study in Latvia (Holma 2017) has revealed that, in general, the country's population still lacks knowledge and competence in information literacy, including the ones in the field of health. The results of the study have demonstrated that a significant part of Latvians (one in three) believes that their information literacy and life skills in the field of health are especially unsuccessful and they need to be improved on both personal and public levels.

In the context of the access to healthcare, along with digital and information literacy, an important role is also played by the so-called medical literacy of the population awareness, education of the population in medical matters (Volkova, 2020). In the Latvian health care system, there is evidence of inequality of access to information; the residents of Latvia consider that they are not sufficiently aware of their rights to healthcare. A research devoted to the study of patient satisfaction with health services (Putnina \& Brants, 2018) states that patients lack basic information. For example, only $36 \%$ of respondents indicated that they knew or partially knew how the information about publicly paid healthcare could be used in order to receive faster service.

Estonia was one of the first countries in the world to switch to the e-health model. However, it did not happen immediately. The project of "digitization" of the healthcare system was one of the elements of a large-scale state 
programme to deploy Internet technologies in the public administration and business that the neighbouring country has been consistently implementing since the 1990s. By the time e-health was set up, Estonian residents already had an opportunity to vote on the Internet in elections and to file tax returns, to approach to banks, to state and municipal institutions without leaving home. But the most important thing is that in 2008, when Estonian medical institutions started to switch to a new format of their work, in the country, almost all its residents had their ID cards with a chip and a possibility of electronic signature that allowed to identify any user. This circumstance increased the public confidence in the innovations, provided a possibility for data security control and allowed to deploy a fairly wide package of services in the system at once.

In February 2017, at the World Government Summit, the Estonian electronic healthcare system was awarded the prize for the best technological solution. The award expresses appreciation to the government, which provides efficient and quality services through technological solutions. Innovative projects that change people's lives for the better are honoured.

\section{CONCLUSION}

Our analysis of the deployment of the achievements of digital medicine considered on the experience of creating and using the e-health system in Latvia confirms the complexity and multidimensionality of the process of mastering the latest technologies, in this case affecting the deep foundations of interaction between individual and society. The process is gradually moving away from a simple and rather primitive sphere of interaction of medical institutions with patients into an ever-expanding network of communications with a difficultly predictable number of subjects that directly or indirectly affect the health and quality of life of the population, ideally - without any geographical restrictions. Accessibility and quality of medical care is moving further away from a simple solving of purely economic problems: it requires ever more careful consideration and solution of technological development problems in the social subsystem of society, information literacy of the entire population of the country, and formation of a new management culture. The further study of this issue requires new research efforts, the use of other analysis tools (SWOT, cluster analysis, methods of social psychology, etc.).

As is widely known, SWOT analysis is one of the most effective tools in strategic management, including at the national level. Thus, our SWOT analysis (Menshikov \& Volkova, 2019) demonstrates and explains that the development of new technologies on the example of the e-health system requires the targeted efforts of the entire society, and not just of one of its subsystems. Numerous internal and external factors, both stimulating and hindering the adoption of technological innovations, should be timely taken into account in strategic planning, and the problems to be identified should be solved not only by ICT specialists, but by a qualified team with the involvement of representatives of social sciences (economists, sociologists, lawyers and others). Latvia has this kind of experience, when a topical theme under analysis is subjected to a kind of deep audit by a sufficiently qualified team of diversified specialists within the framework of the periodical inter-university projects "Latvia. Human Development Report". In our opinion, it is advisable that the upcoming project to be carried out by Latvian researchers should be devoted to the topical issue of e-health. In this research project, it is significant to use the experience of specialists from other countries where similar studies have been being conducted (Georgia, Ukraine, Poland) and the experience of international cooperation in the framework of other social projects has already been accumulated. is important to use the experience of specialists from other countries where similar studies are being conducted (Georgia, Ukraine, Poland) and the experience of such cooperation has already been accumulated in the framework of other social projects.

\section{REFERENCES:}

Al-Shorbaji, N. (2013). The World Health Assembly Resolutions on eHealth: eHealth in Support of Universal Health Coverage. Methods of Information in Medicine, 52(6). doi:10.1055/s-0038-1627062

Apinis, P. (2020, March 20). Pēteris Apinis: Covid-19 un pārspīlējumu politika. Retrieved from Latvijas Avīze: https://veselam. la.Iv/peteris-apinis-covid-19-un-parspilejumu-politika (In Latvian)

Arak, P., \& Wójcik, A. (2016-2017). Transforming eHealth into a political and economic advantage. Polityka INSIGHT . Retrieved from http://ec.europa.eu/newsroom/document.cfm?doc_id=45571

Baltniews. (2020, March 17). Kak e-zdorovse stalo "chernoj dyroj», pogloshchayushchej denıgi gosudarstva i pacientov. Retrieved from https://lv.baltnews.com/ekonomika_online_novosti/20200317/1023761191/Kak-e-zdorove-stalochernoy-dyroy-pogloschayuschey-dengi-gosudarstva-i-patsientov.html (In Russian)

Black Book Research (2017) Healthcare Blockchain Interest Heats Up: Black Book Survey. Available at: https://www. prnewswire.com/news-releases/update---healthcare-blockchain-interest-heats-up-black-book-survey-300530281.html (In English)

Codagnone C., Lupiañez-Villanueva F. (2013) Benchmarking Deployment of eHealth among General Practitioners. Final Report. European Commission. Available at: https://ec.europa.eu/digital-single-market/en/news/benchmarking-deploymentehealth-among-general-practitioners-2013-smart-20110033 (In English)

Deloitte Centre for Health Solutions. (2015). Connected health: How digital technology is transforming health and social care. 
Retrieved from https://www2.deloitte.com/content/dam/Deloitte/uk/Documents/life-sciences-health-care/deloitteuk-connected-health.pdf

Ensor, T., \& Cooper, S. (2005). Influencing the Demand Side of Purchasing. In A. Preker, \& J. Langenbrunner, Spending Wisely. Buying Health Services for the Poor. Washington: The world bank. Retrieved from https://www.researchgate.net/ publication/262765974_Overcoming_barriers_to_health_service_access_-_influencing_the_demand_side

Eurobarometer (2017) Special Eurobarometer 460: Attitudes towards the impact of digitalisation and automation on daily life

European Commission. (2019, Septembris 27). The Digital Economy and Society Index (DESI). Retrieved from https:// ec.europa.eu/digital-single-market/en/desi

European Commission. (2020). DESI by components. Retrieved from: https://digital-agenda-data.eu/datasets/desi/

visualizations Gabaliṇa D. (2012) E-veselība Latvijā. Veselïbas Ministrija. Available at: http://www.veseliba.gov.lv/uploads/ files/502cadc0b5990.pdf (In Latvian)

Galickih, V. (2020, Mart 31). Slezhka za koronavirusom: kak mobilınye operatory pomogut ES borotısya s epidemiej. Retrieved from https://www.eurointegration.com.ua/rus/experts/2020/03/31/7108176/ (In Russian)

Harari Yu.N. (2018) Bolshinstvolyudey ne osoznayut, chtoproishodit.:Rechizrailskogoistorika v Davose.Available at: https://bykvu. com/bukvy/84181-bolshinstvo-lyudej-ne-osoznayut-chto-proiskhodit-rech-izrailskogo-istorika-v-davose(In Russian)

Holma, B. (galv.red.). (2017). Latvija. Pārskats par tautas attīstību 2015/2016. Dzīves meistarība un informācijpratība. Rīga: LU Sociālo un politisko pētījumu institūts. Retrieved from https://www.szf.lu.lv/fileadmin/user_upload/szf_faili/Petnieciba/ sppi/tautas/original/TAP_2015-2016.pdf (In Latvian)

Latulippe K., Hamel C., Giroux D. (2017, April) Social Health Inequalities and eHealth: A Literature Review With Qualitative Synthesis of Theoretical and Empirical Studies. Journal of Medical Internet Research, 19(4). doi:10.2196/jmir.6731

LatvijasRadio 4. (2019, March 16). "Ni proglotits, ni vyplyunuts". Glava Minzdrava ob "E-zdorovse". Retrieved from: https:// rus.Ism.Iv/statja/novosti/obschestvo/ni-proglotit-ni-viplyunut-glava-minzdrava-ob-e-zdorove.a312764/ (In Russian)

Lyadova A. (2018) Digital health: myth or reality. Available at: http://hdl.handle.net/10995/58996 (In Russian)

Menshikov V., Volkova O., Stukalo N., Simakhova A. (2017, December) Social Economy as a Tool to Ensure National Security. Journal of security sustainability issues. Volume 7, number 2.31-51. Available at: http://jssidoi.org/jssi/uploads/ papers/26/Menshikov_Social_economy_as_a_tool_to_ensure_national_security.pdf(In English)

Menshikov, V., \& Volkova, O. (2019). Digitalization for increased access security to healthcare services in Latvia. Journal of Security and Sustainability Issues, 9(1). doi:https://doi.org/10.9770/jssi.2019.9.1(13)

Nering, K., Gunkelı, E. (2020, April 20). Messendzhery i zashchita dannyh: chto bolshe podhodit dlya raboty na domu? Retrieved from dw.com: https://p.dw.com/p/3b4Gf (In Russian)

Novillo-Ortiz, D., Dumit, E. M., D’Agostino, M., Becerra-Posada, F., Kelley, E. T., Torrent-Sellens, J., . . . Saigí-Rubió, F. (2018). Digital health in the Americas: advances and challenges in connected health. BMJ Innov., 4(3). doi:10.1136/ bmjinnov-2017-000258

OECD. (2010). Improving Health Sector Efficiency The Role of Information and Communication Technologies. OECD publisher. Retrieved from https://ec.europa.eu/health//sites/health/files/eu_world/docs/oecd_ict_en.pdf

OECD/EU. (2016) Health at a Glance: Europe 2016 - State of Health in the EU Cycle, OECD Publishing, Paris. http://dx.doi. org/10.1787/9789264265592-en

Putniṇa, A., \& Brants, M. (2018). Pētījums par pacientu apmierinātību ar veselības aprūpes pakalpojumu kvaitāti. Gala ziṇojums. SIA "Projektu un kvalitātes vadība", SIA "Aptauju Centrs", Rīga. Retrieved from http://petijumi.mk.gov.Iv/ sites/default/files/title_file/Zinojums_Pacientu_apmierinatiba_ar_veselibas_aprupes_pakalp_kvalitati.pdf (In Latvian)

Roth, S., Landry, M., \& Parry, J. (2015). Universal health coverage by design: ICT - enabled solutions are the future of equitable, quality health care and resilient health systems. ADB Briefs, 36. Retrieved from https://www.adb.org/sites/default/files/ publication/160117/universal-health-coverage-design-ict.pdf

Shamshurin D.A. (2018, Juny) Digital media as cultural globalization factor. Mezhdunarodnyj nauchno-issledovatelıskij zhurnal, № 6 (72), Chast) 2, DOI: https://doi.org/10.23670/IRJ.2018.72.6.036(In Russian)

StartUp Health Insights (2018) Global Digital Health Funding Report. Available at: https://www.startuphealth.com/insights-reports

Townsend P. (2010) The meaning of poverty. The British Journal of Sociology. DOI: https://doi.org/10.1111/j.14684446.2009.01241.x

Volkova, O. (2020). Informacionnoe neravenstvovzdravoohranenii: institucionalınyjaspekt. Proceedings of the international scientific conferences of faculty of social sciences of Daugavpils University. The materials of the International Scientific Conference "Social Sciences for Regional Development 2019». Part 1. Issues of sociology. Retrieved from http://humanitiessocial.lv/wpcontent/uploads/2020/04/SZF-krajums_I_Sociologijas-aktualitates_2020_BEZ-ISBN.pdf (In Russian)

WHO. (2016 a) From innovation to implementation - eHealth in the WHO European Region. Report. Available at:http://www. euro.who.int/_data/assets/pdf_file/0012/302331/From-Innovation-to-Implementation-eHealth-Report-EU.pdf WHO.

(2016 b). Global difusion of eHealth: making universal health coverage achievable. Report of the third global survey on eHealth. Retrieved from http://africahealthforum.afro.who.int/first-edition/IMG/pdf/global_diffusion_of_ehealth_-_ making_universal_health_coverage_achievable.pdf 